\title{
Review of Industrial Activities: A Threat to Biodiversity and Ecotourism Development in Delta State, Nigeria
}

\author{
Ajani, F. \\ Pudie, A. \\ Department of Wildlife and Ecotourism Management \\ University of Ibadan \\ Ibadan. Nigeria
}

\begin{abstract}
Biodiversity is a term that describes the variety of living beings on earth. It encompasses microorganisms, plants, animals and ecosystems such as coral reefs, forests, deserts, valleys, hills, water bodies, indigenous cultural activities and festivals of a people including mode of worship. Biodiversity loss, which is a result of environmental degradation, is a situation in which a part of the natural environment is damaged. It could be damage to the land, water, or air. The major Industrial activities that are threats to biodiversity in Delta State are oil spillage and gas flaring. These activities lead to serious biodiversity loss, forest depletion, mangrove degradation, environmental pollution, fisheries depletion, flooding, unhealthy environment, poverty and even death and these leaves no room for tourism development. Delta state is well endowed with biodiversity, and this could be harnessed for ecotourism purpose, thus generating revenue for the state and project the cultural identity of the state while empowering the local people. However, the biodiversity and ecotourism development of the state is been threatened. Biodiversity destruction has serious and complex adverse effects on tourist visitation, and the economies of both Delta State and individual households in the state. This study is therefore aimed at identifying some of the ecotourism attractions of Delta State, various threats to these attractive biodiversities and to explore the potential effects of these destructions on ecotourism development in the State.
\end{abstract}

Keywords: Ecotourism, Biodiversity threats, Environmental degradation, Delta state

\section{Introduction}

Biodiversity is the variety of life in all of its manifestations encompassing all forms (plants, animals, microorganisms) and at all levels of biological organizations which include genetic diversity and ecosystem (Christet al., 2003, Gaston and Spices, 2004, Meduna et al,.CBD, 2012)

The International Ecotourism Society (TIES) defined ecotourism as "responsible travel to natural areas that conserves the environment, sustains the well being of the local people and involves interpretation and education". Ecotourism therefore is responsible tourism, which is ecologically and culturally sensitive (Buchshaum, 2004; Drumm and Moore, 2002). According to Kiper, (2013), ecotourism helps in community development by providing the alternative source of livelihood to local community with the aim of conserving resources, especially biological diversity, and maintain sustainable use of resources, which can bring ecological experience to travelers, conserve the ecological environment and gain economic benefit. Ecotourism helps in involving local community for the conservation of the ecology and biodiversity of the area (Kiper, 2013).Environmental factors form the basic resource upon which the tourism industry depends to thrive and grow, and threats to the environment can affect the viability of the tourism industry (Puczto and Ratz, 2000).

Delta state is located in the Niger Delta region of Nigeria, a popular region for oil and gas exploration and exploitation. Niger Delta is among the 10 most important wetland and marine ecosystems in the world. It consists of diverse ecosystems of mangrove swamps, fresh water swamps and rain forests (Kadafa, 2012). The ecosystem of the area is highly diverse and supportive of the numerous species of the terrestrial and aquatic fauna and flora as well as human life (Uyigue and Agho2007). Niger Delta is the largest wetland in Africa and third largest in the world (Powel et al, 1985) but due to oil exploration the area is now characterized by contaminated streams and rivers, forests destruction and biodiversity (Kadafa, 2012). According to Onuoha, (2008), oil and gas pipelines have been installed covering $7000 \mathrm{~km}$ to enhance the distribution of crude oil products to other parts of the country. The installation of these pipelines involved clearing large areas of habitats to make pipeline tracks. The oil rich Niger Delta produces up to 2 million barrels of crude oil a day (238million liters of crude oil a day) which has placed Nigeria as the $9^{\text {th }}$ oil producing country in the world (Zabbey, 2009). Such extensive oil extraction has come at great environmental and social cost. 
The Nigerian oil industry which primarily extracts oil amongst the Niger Delta mangrove forests has consequently deforested mangrove ecological zones for drilling purposes and deteriorated the health of the surrounding mangroves (Langeveld and Delany, 2014). Petroleum has toxicological impact on the mangrove trees, but also causes direct physical damage. According to Langeveld and Delany (2014), when placed in the presence of crude oil, greater than 95\% of the mangrove seedling died. Petroleum, which comprises hydrocarbon compound contaminants such as PAHs (Polycyclic Aromatic Hydrocarbon), has been connected to plant chlorophyll damage. As a result of PAH absorption, mangrove leaf pigmentation is altered, limiting photosynthesis. Regardless of oil toxicity or soil absorption capacity, mangroves can be fatally damaged from surface oil spills as oil coats cells that allow oxygen to reach the rots, resulting in Oxygen deprivation and incapability of necessary biological processes (Egwurugwu et al. 2013).

The oil industry located within this region has contributed immensely to the growth and the development of the country which is a fact that cannot be disputed. But unsustainable industrial activities have rendered the biodiversity of Delta State and the Niger Delta region as one of the five most severely damaged petroleum ecosystem (Kadafa, 2012). Delta state is well endowed with biodiversity that could be harnessed for ecotourism development but however the biodiversity of the state is been threatened. Ecotourism is dependent on biodiversity and as such it cannot thrive successfully amidst adverse biodiversity threats.

Environmental factors form the basic resource upon which the tourism industry depends to thrive and grow, and threats to the environment can affect the viability of the tourism industry (Puczto and Ratz, 2000). Many studies have been carried out in Niger-Delta. Ogbija et al., (2015) worked on the Effects of Environmental Degradation on Human Health in Selected Oil Communities in Delta State, Atubi, (2015) looked into the Effects Of Oil Spillage On Human Health In Producing Communities Of Delta State. The Impact Of Oil Exploration, Extraction And Transport On Mangrove Vegetation And Carbon Stocks In Nigeria, was researched by Langeveld And Delany, (2014).Kadafa, (2012) worked on Environmental Impacts of Oil Exploration and Exploitation in the Niger Delta of Nigeria, but much has not been done on the effect of these industrial activities on biodiversity degradation as concerns ecotourism.

The objectives of this work are to identify some of the ecotourism attractions in Delta State, to identify various threats to its biodiversity and to explore potential effects of these destructions on biodiversity and ecotourism management.

\section{Ecotourism Attractions in Delta State}

Table 1: List of Tourist Sites in Delta State

TOURIST ATTRACTIONS $\quad$ LOCATIONS

\begin{tabular}{ll} 
Abraka turf and country club & Abraka \\
Rivotel hotel and Golf resort & Abraka \\
Gordon river resort and McCarthy beach & Abraka \\
River Ethiope water source & Umuaja \\
Otuogu beach & Asaba \\
Chief Nana's palace living history museum & Koko \\
Kwale game reserve & Kwale \\
Mungo park house & Asaba \\
Araya Bible site & Isoko \\
Lander Brothers Anchorage & Asaba \\
\hline
\end{tabular}

Source: Atubi, 2015 


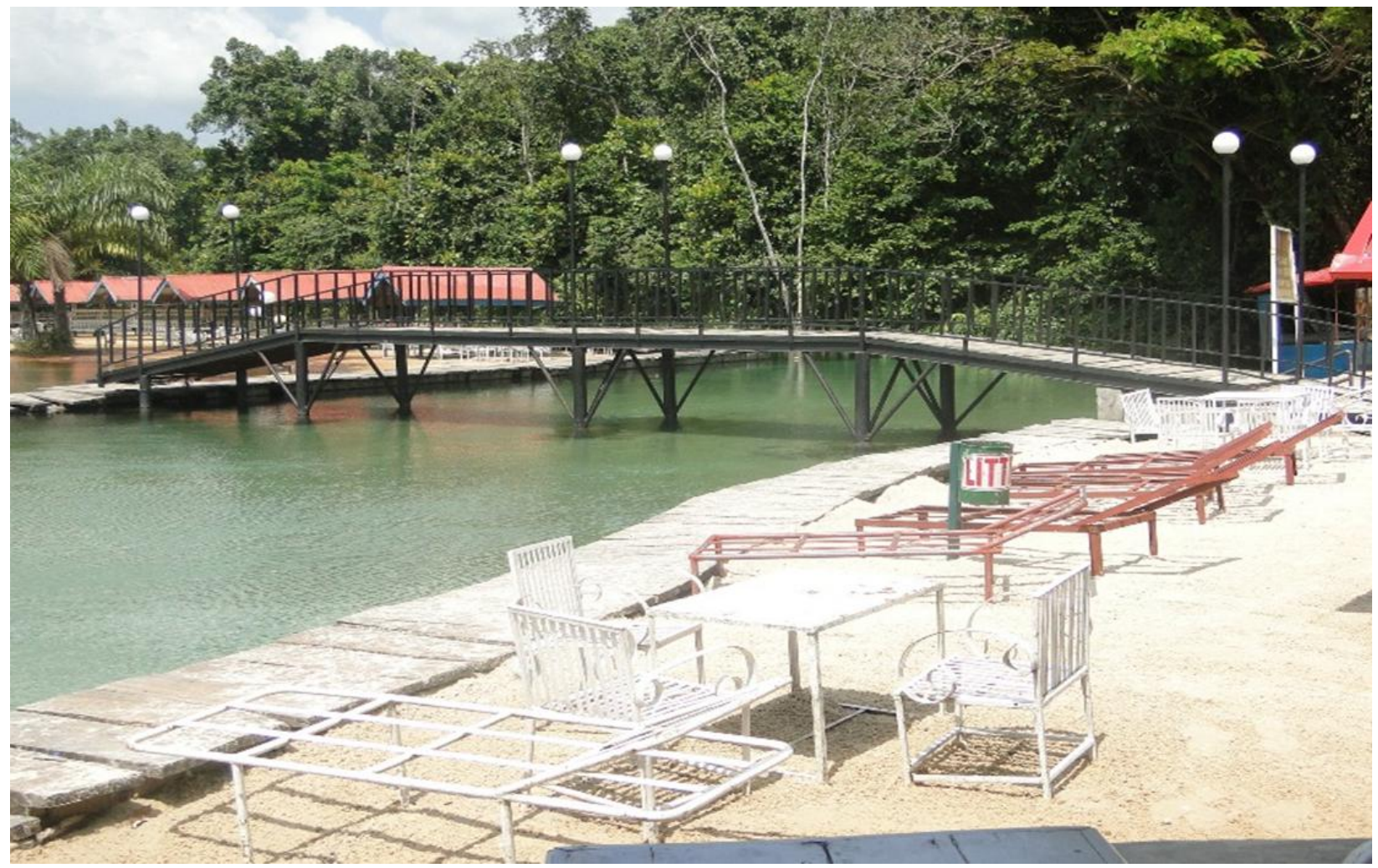

Plate1: Gordon River Resort

Source: Travel hub, 2017

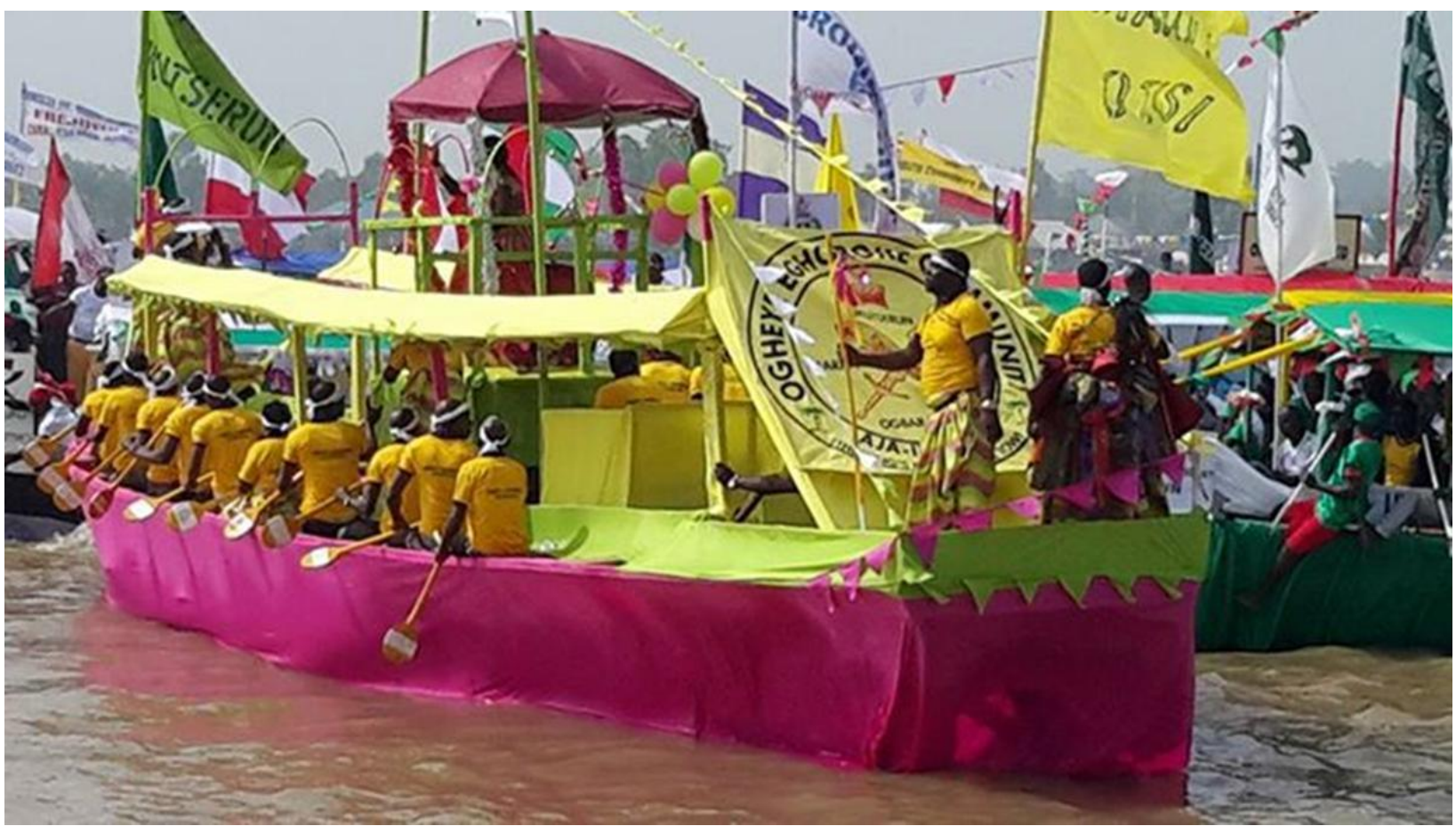

Plate 2: Boat Regatta in Warri

Source: Nigeriagalleria 2017 


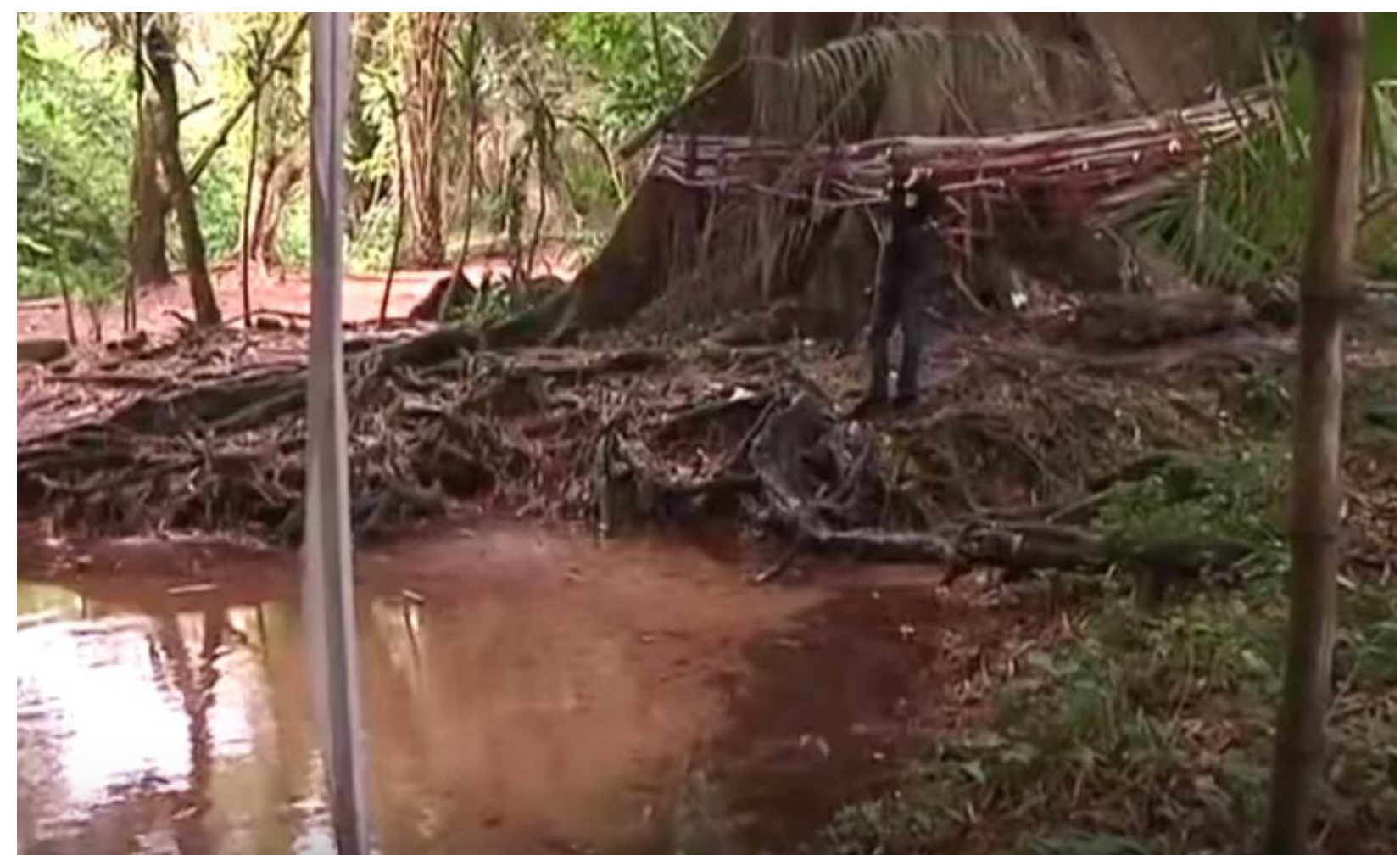

\section{Plate 3: River Ethiope source}

Source: Easy pictures, 2017

\section{Threats to Biodiversity}

\section{OIL SPILLAGE}

According to Baird (2010), 50\% of all spills occur due to pipeline and tanker accidents Other causes include sabotage $(28 \%)$ and oil production operations (21\%), with $1 \%$ of the spills being accounted for by inadequate or non-functional production equipment. Pipelines which have an estimated life span of about 15years are as old as 20-25years (Brownwen, 1999).

UNDP (2006) reports stated that there has been a total of 6, 817 oil spills between 1976 and 2001, which accounted for a loss of 3million barrels (357million litres) of oil, which more than 70\% was not recovered. Ogbijaet al. (2015), said "Nothing is sacred in this breathless search for new oil; Pristine forest, sacred groove, ecologically fragile environments and even, internationally recognized conservation site are not left untouched in this quest for new oil fields." Oil and gas pipelines have been installed covering about $7000 \mathrm{~km}$ to enhance distribution of crude oil products to others parts of the country (Onuoha, 2008). According to Nemibarini (2004) most incidence of oil spillage have occurred in the mangrove swamp forest, which is the one of the most productive ecosystem rich in fauna and flora .

\section{Effects of Oil Spillage}

1. Birds and mammals are vulnerable to oil spills when their habitats becomes contaminated and this may reduce reproduction rates, survival and physiological impairment (Briggs et al., 1996)

2. In water, oil films floating on the water surface prevents natural aeration and leads to death of fresh water or marine life and on land lead to retardation of vegetation growth, cause soil infertility for long period of time (Ukoli, 2005)

3. According to Edge and Thompson (2010), Barium and Chromium are usually found in oil spill sites and skin contact with chromium compounds can cause skin ulcers. Ingesting large amount of chromium can cause stomach upset and ulcers, kidney and liver damage and even death. Barium water solution may cause a person to experience breathing difficulties, increased blood pressures heart rhythm changes and stomach irritation 


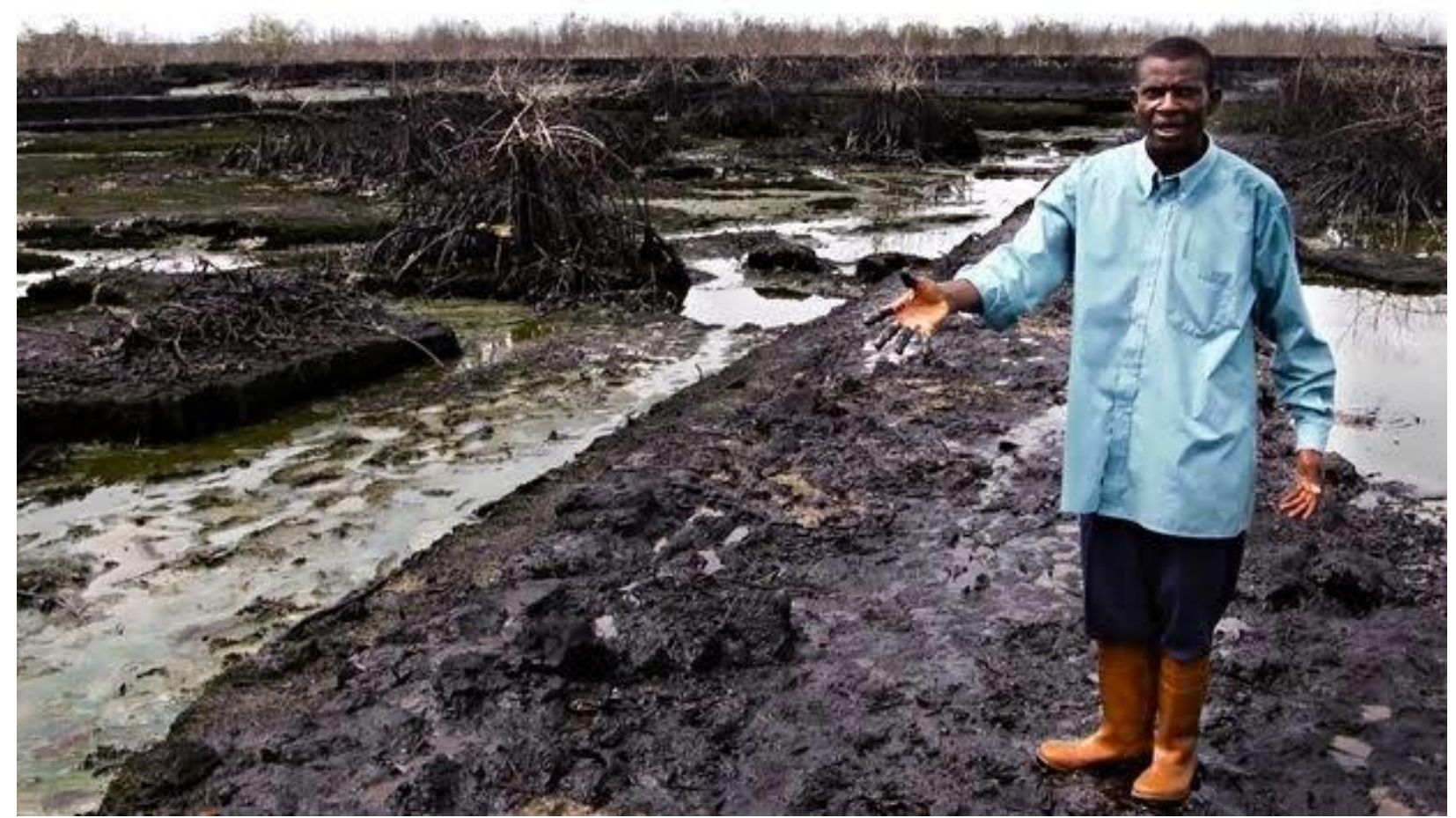

Plate 4: A Man at an Oil Spill Site in Delta State

Source: Brownwen, 1999

Table 2: Some severely oil polluted sites in the Niger Delta

\begin{tabular}{lll}
\hline Location & Environment impacted & Nature of incidence \\
\hline Opuekebe & Barrier forest island & Salt water intrusion \\
Jones creek & Mangrove forest & Spillage and burning \\
Ubeji & Mangrove forest & Refinery waste \\
Ughelli & Freshwater swamp forest & Oil spillage -wellhead leak \\
Jesse & Freshwater swamp & Product leak and burning \\
Ajato & Mangrove forest & Oil spillage incidence \\
Ajala & Freshwater swamp forest & Oil spillage incidence \\
Uzere & Freshwater swamp forest & Oil spillage incidence \\
Afiesere & Freshwater swamp forest & Oil spillage incidence \\
Kwale & Freshwater swamp forest & Oil spillage incidence \\
Olomoro & Freshwater swamp forest & Oil spillage incidence \\
Ekakpare & Freshwater swamp forest & Oil spillage incidence \\
Ughuvwughe & Freshwater swamp forest & Oil spillage incidence \\
Ekerejegbe & Freshwater swamp forest & Oil spillage incidence \\
Ozoro & Freshwater swamp forests & Oil spillage incidence \\
Odimodi & Mangrove forest & Oil spillage incidence \\
Ogulagha & Mangrove forest & Oil spillage incidence \\
Otorogu & Mangrove forest & Oil spillage incidence \\
Macraba & Mangrove forest & Oil spillage incidence \\
\hline Adapted from Kadafa & &
\end{tabular}

Adapted from Kadafa, 2012

\section{Gas Flaring}

Gas flaring is the combustion of unutilized excess gas during oil exploration and exploitation which lead to the emission of Carbon (IV) Oxide, Carbon (II) Oxide, Nitrogen (IV) Oxide, Hydrogen Sulphide, Sulphur (IV) Oxide, soot, smoke, heavy metals like iron $(\mathrm{Fe})$, Manganese $(\mathrm{Mn})$ Copper $(\mathrm{Cu})$, Cobalt $(\mathrm{Co})$, Lead $(\mathrm{Pb})$ and $\mathrm{Chromium}(\mathrm{Cr})$ (Emumejaye, 2012). Malfunctioning gas furnaces sometimes emit poisonous Carbon Monoxide which if inhaled deprives people of necessary Oxygen. 
Table 3: Flaring of Natural Gas in Major Producing Countries (\%) of Gross Production in 1991

\begin{tabular}{ll}
\hline COUNTRY & $\%$ \\
\hline United States of America & 0.06 \\
Holland & 0.0 \\
Britain & 4.3 \\
Former Union of Soviet Socialist Republic (USSR) & 1.5 \\
Mexico & 5.0 \\
OPEC Countries & \\
Nigeria & 76.0 \\
Libya & 21.0 \\
Saudi Arabia & 20.0 \\
Algeria & 19.0 \\
OPEC Total & 18.0 \\
World Total & 14.8 \\
\hline
\end{tabular}

Source: World Bank Report, 1995

TABLE 2 : Extent of gas flaring in SSA countries (1995-2010)

$\begin{array}{lllll}\text { Countries } & \mathbf{1 9 9 5} & \mathbf{2 0 0 0} & \mathbf{2 0 0 5} & \mathbf{2 0 1 0} \\ \text { Angola } & 4.51 & 5.94 & 4.72 & 4.08 \\ \text { Cameroon } & 1.15 & 1.19 & 0.97 & 0.92 \\ \text { Chad } & 0.00 & 0.00 & 0.09 & 0.05 \\ \text { Congo } & 1.08 & 2.02 & 1.79 & 1.88 \\ \text { Cote d'Ivoire } & 0.06 & 0.09 & 0.04 & 0.09 \\ \text { DRC } & 0.53 & 0.43 & 0.44 & 0.39 \\ \text { Eq. Guinea } & 0.61 & 1.21 & 1.36 & 0.39 \\ \text { Ghana } & 0.00 & 0.00 & 0.01 & 0.02 \\ \text { Gabon } & 2.15 & 2.54 & 2.36 & 1.68 \\ \text { Nigeria } & \mathbf{2 7 . 0 9} & \mathbf{2 7 . 1 9} & \mathbf{2 1 . 2 5} & \mathbf{1 5 . 1 8} \\ \text { South Africa } & 0.06 & 0.13 & 0.14 & 0.10 \\ \text { Global } & 154.97 & 164.90 & 171.65 & 133.90\end{array}$

In billion cubic metres

Source: NOAA (2010)

\section{Environmental Implications Of Gas Flaring}

- Climate Change

Gas flaring contributes to climate change, which has serious implications for both Nigeria and the rest of the world (Ajugwo, 2013). The burning of fossil fuel, mainly coal, oil and gas-greenhouse gases-has led to warming up the world and is projected to get much, much worse during the course of the 21 st century according to the intergovernmental panel on climate change (IPCC). This scientific body was set up in 1988 by the UN and the World Meteorological Organization to consider climate change. Climate change is particularly serious for developing countries, and Africa as a continent is regarded as highly vulnerable with limited ability to adapt. Gas flaring contributes to climate change by emission of carbon dioxide, the main greenhouse gas. 
Venting of the gas without burning, a practice for which flaring seems often to be treated as a synonym, releases methane, the second main greenhouse gas. Together and crudely, these gases make up about $80 \%$ of global warming to date.

- Acid Rain

Acid rains have been linked to the activities of gas flaring (FOE, 2004 and Medilinkz, 2010). Corrugated roofs in the Delta region have been corroded by the composition of the rain that falls as a result of flaring. The primary causes of acid rain are emissions of Sulphur dioxide $\left(\mathrm{SO}_{2}\right)$ and Nitrogen oxide (NO) which combine with atmospheric moisture to form sulfuric acid and nitric acid respectively. Size and environmental philosophy in the industry have very strong positive impact on the gas-flaring-related $\mathrm{CO}_{2}$ emission (Hassan and Konhy, 2013).

Acid rain acidifies lakes and streams and damages vegetation. In addition, acid rain accelerates the decay of building materials and paints. Prior to falling to the earth, $\mathrm{SO}_{2}$ and $\mathrm{NO}_{2}$ gases and their particulate matter derivatives, sulfates and nitrates, contribute to visibility degradation and harm public health. (Ajugwo, 2013)

- Agriculture

The flares associated with gas flaring give rise to atmospheric contaminants. These include oxides of Nitrogen, Carbon and Sulphur $\left(\mathrm{NO}_{2}, \mathrm{CO}_{2}, \mathrm{CO}, \mathrm{SO}_{2}\right)$, particulate matter, hydrocarbons and ash, photochemical oxidants and Hydrogen Sulphide $\left(\mathrm{H}_{2} \mathrm{~S}\right)$ (Obioh, 1999 and Kindzierski, 2000) These contaminants acidify the soil, hence depleting soil nutrient. Previous studies have shown that the nutritional value of crops within such vicinity are reduced (Imevbore and Adeyemi, 1981). In some cases, there is no vegetation in the areas surrounding the flare due partly to the tremendous heat that is produced and acid nature of soil pH (Ubani and Onyejekwe, 2012).

The effects of the changes in temperature on crops included stunted growth, scotched plants and such other effects as withered young crops (Orimoogunje et al., 2010), and as a result, the soils of the affected area are fast losing their fertility and capacity for sustainable agriculture due to the acidification of the soils by the various pollutants associated with gas flaring in the area.

- Health Implications

Adverse Effects

The implication of gas flaring on human health are all related to the exposure of those hazardous air pollutants emitted during incomplete combustion of gas flare. These pollutants are associated with a variety of adverse health impacts, including cancer, neurological, reproductive and developmental effects. Deformities in children, lung damage and skin problems have also been reported (Ovuakporaye et al., 2012).

Hematological Effects

Hydrocarbon compounds are known to cause some adverse changes in hematological parameters. These changes affect blood and blood-forming cells negatively and could give rise to anemia (aplastic), pancytopenia and leukemia (Kindzierski, 2000).

Other Effects

- Economic Loss

Aside from the health and environmental consequences of gas flaring, the nation also loses billions of dollars worth of gas which is literally burnt off daily in the atmosphere. Nigeria has recorded a huge revenue loss due to gas flaring and oil spillage (Effiong and Etowa, 2012). Though more than $65 \%$ of governmental revenue is from oil (Arowolo and Adaja, 2011), it is estimated that about $\$ 2.5$ billion is lost annually through gas flaring in government revenues.

- Pollution

Drilling mud and oil sometimes find their way to the streams, surface waters and land thus making them unfit for consumption nor habitable by man or animal. This problem has been produced by a range of international oil companies which have been in operation for over four decades. The economic and environmental ramifications of this high level of gas flaring are serious because this process is a significant waste of potential fuel which is simultaneously polluting water, air, and soil in the Niger Delta (Ajugwo, 2013)

\section{Effect of Heavy Metals on Humans}

Humans are exposed to those heavy metals through inhalation of polluted air from gas flaring, consumption of contaminated drinking water or consumption of contaminated food. Heavy metals are metallic chemical elements that have relatively high density and toxic or poisonous at low concentration. Example of heavy metals that are harmful to humans includes Cadmium, Lead, Nickel etc. Chronic exposure to these metals can have serious health consequences. Heavy metals exposure causes serious health effect including reduced growth and development, cancer, organ damage and in extreme cases, death (Manahan, 1994) 
Metals are particularly toxic to the sensitive, rapidly developing systems of fetuses, infants and young children. Some metals such as Lead easily cross the placenta and damage the fetal brain. Childhood exposure to some metals can result in learning difficulties, memory impairment, damage to the nervous system and behavioral problem aggressiveness and hyperactivity (WHO, 1994)

\section{Plate 5: Tapioca and smoked fish (a Delta Food)}

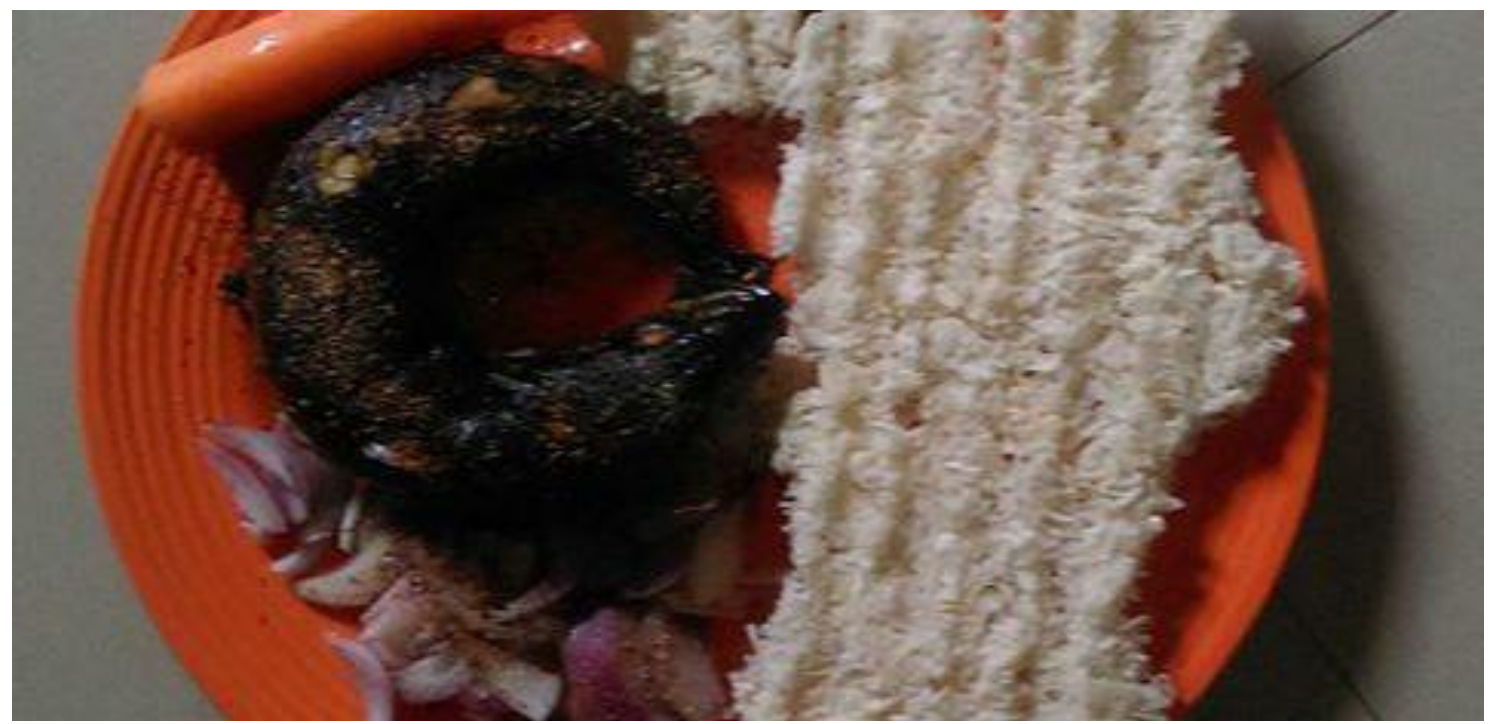

Source: George, 2009

\section{Plate 6: A Woman Drying Tapioca in a Gas Flare Site}

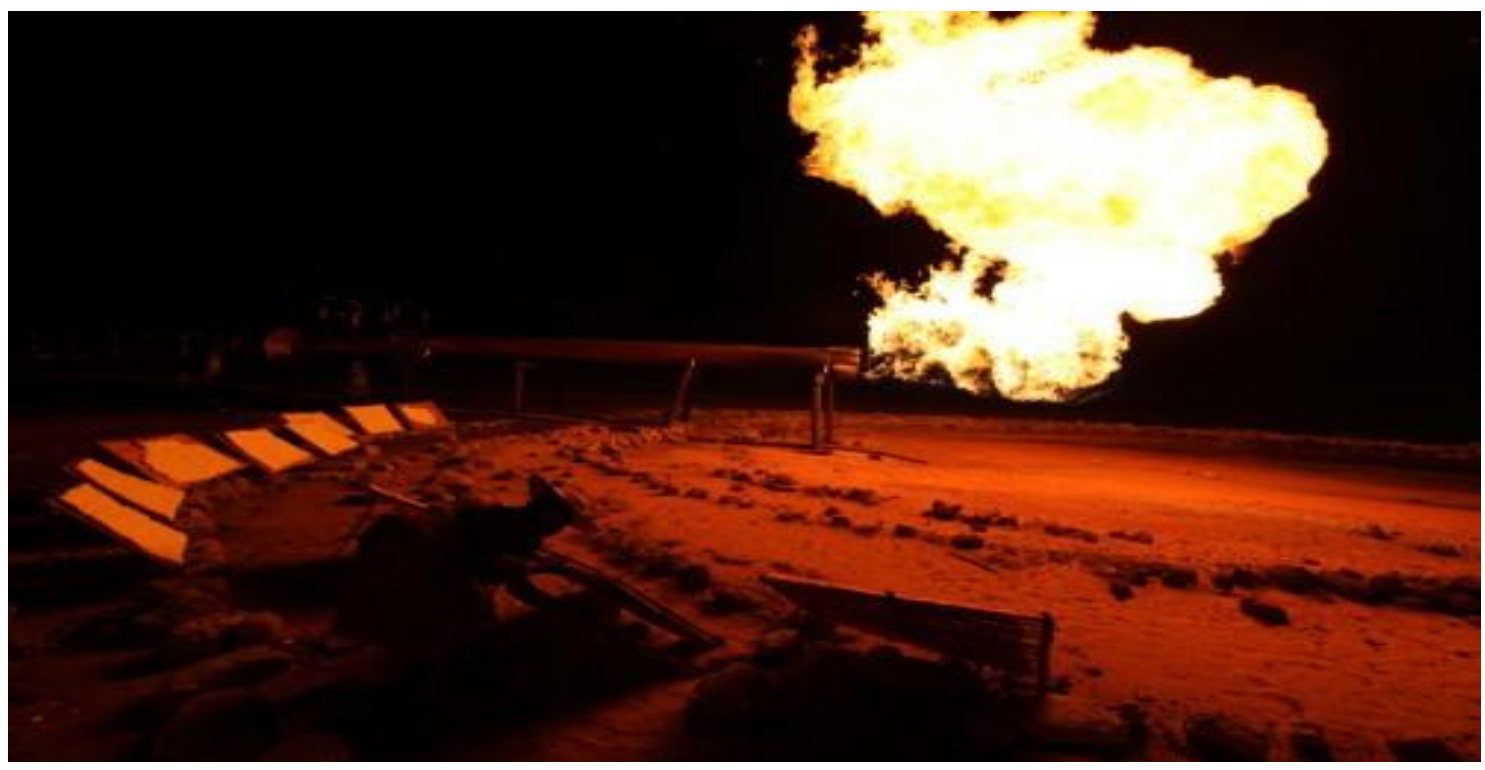

Source: George, 2009

Sample ID 1 and 2 below shows the concentration in $\mathrm{mg} / \mathrm{kg}$ of the heavy metals foundin the sample of tapioca dried with heat from gas flare in Gana flow-station, Agbarha, Delta State, Nigeria while Sample ID 3 and 4 below shows the concentration in $\mathrm{mg} / \mathrm{kg}$ of the heavy metals found in the un-dried sample of tapioca 
Table 4: Concentration in $\mathrm{mg} / \mathrm{kg}$ of heavy metals found in tapioca and WHO Recommended Maximum Heavy Metals Acceptable Limit In Food.

S/N HEAVY METALS SAMPLE ID SAMPLE ID SAMPLE ID SAMPLE ID WHO $\begin{array}{llll}1 & 2 & 3\end{array}$

Recommended 1 maximum (tapioca dried (tapioca dried (un-dried ( un-dried acceptable limit with heat with heat sample of sample of in food $(\mathrm{mg} / \mathrm{kg})$ from gas from gas tapioca) tapioca) flare) flare)

1.
Iron $(\mathbf{F e})$

14.45

6.90

4.45

5.90

$1-3$

13.15

7.40

3.15

6.41

2.

Manganese $\quad 28.90$

27.30

8.90

7.31

$0.1-0.5$

(Mn)

24.35

23.90

4.35

8.92

3. $\quad$ Lead $(\mathbf{P b})$

14.30

38.10

4.30

8.15

2

26.20

38.10

6.20

8.10

4.

Cadmium (Cd)

0.25

0.10

0.25

2

0.35

0.35

0.35

0.35

5. $\quad$ Nickel (Ni)

0.85

0.85

0.85

0.85

$0.5-0.6$

1.05

0.00

1.05

0.45

6

$$
\text { Copper (Cu) }
$$

6.65

14.05

6.65

14.05

$1-3$

6.05

3.40

6.06

3.40

7. Zinc (Zn)

$\begin{array}{ll}11.40 & 6.96 \\ 8.22 & 10.62\end{array}$

5.40

9.96

10-75

8.22

10.62

6.22

8.62

Adapted from Emuajaye, 2012 
Table 6: Effects of Heavy Metals on Humans

\begin{tabular}{|c|c|}
\hline METALS & EFFECTS \\
\hline Iron $(\mathbf{F e})$ & $\begin{array}{l}\text { Excessive accumulation in the human body promotes bacterial growth as } \\
\text { iron is needed in their growth } \\
\text { (b) Cancer harmful effects }\end{array}$ \\
\hline Manganese (Mn) & $\begin{array}{l}\text { (a) High levels of manganese cause gene mutation. } \\
\text { (b) It may also cause Parkinson disease. }\end{array}$ \\
\hline Lead $(\mathrm{Pb})$ & $\begin{array}{l}\text { (a) Loss of appetite, nausea, abdominal cramps, anemia and weakness. } \\
\text { (b) Kidney infection (nephritis) } \\
\text { (c) Brain damage, mental deficiency leading to abnormal behavior } \\
\text { (d) Lead in water combines with the mucus of the gill covers resulting in } \\
\text { the interference with normal respirationcausing the death of fish by } \\
\text { asphysciation (suffocation). }\end{array}$ \\
\hline Cadmium (Cd) & $\begin{array}{l}\text { (a) High blood pressure } \\
\text { (b) Kidney and liver damage } \\
\text { (c) Destruction of testicular tissue and red blood cells } \\
\text { (d) Bronchitis } \\
\text { (e) Cancer } \\
\text { (f) Inactivated enzyme } \\
\text { (g) Abnormal swelling of the lung } \\
\text { (h) Abdominal pains (i) Nausea, anemia, vomiting dizziness and diarrhea }\end{array}$ \\
\hline Nickel (Ni) & $\begin{array}{l}\text { (a) Liver cancer } \\
\text { (b) Kidney failure } \\
\text { (c) Asthma }\end{array}$ \\
\hline Copper $(\mathbf{C u})$ & $\begin{array}{l}\text { (a) Stomach and intestinal distress resulting in vomiting, diarrhea, stomach } \\
\text { cramps } \\
\text { (b) Liver disorder } \\
\text { (c) Water polluted with copper kills water plants and fish. }\end{array}$ \\
\hline Zinc $(\mathbf{Z n})$ & $\begin{array}{l}\text { (a) Depress the immune system leading to the invasion of the body by } \\
\text { diseases. } \\
\text { (b) Accelerates thegrowth of prostatecancer andcontribute to coloncancer } \\
\text { (c) Nausea, vomiting, diarrhea,stomach, poor muscleco-ordination, } \\
\text { fatigueand possible kidneyfailure. } \\
\text { (d) Toxic to plant at higher level }\end{array}$ \\
\hline
\end{tabular}

Adapted from Emumejaye, 2012

\section{Effect of Biodiversity Destruction on Ecotourism}

Ecotourism is a biodiversity dependent sector and has a long-term interest in its protection and conservation. At the same time, when developed and managed in a sustainable way, tourism can be instrumental in safeguarding biodiversity. (UNWTO, 2010). Every year, millions of tourists globally, fulfill their urge to see and experience the natural world; snorkelling among coral reefs; wildlife spotting on safari; trekking through rainforests. All these activities depend on healthy and intact ecosystems. Even a beach holiday requires clean waters and a functioning coastal ecosystem.

According to a study carried out by a team of Nigerian and international environmental experts in 2006 (NCF, 2006), the Niger Delta is "one of the world's most severely petroleum-impacted ecosystems". They stated: "The damage from oil operations is chronic and cumulative, and has acted synergistically with other sources of environmental stress to result in a severely impaired coastal ecosystem and compromised the livelihoods and health of the region's impoverished residents." This has posed as a serious challenge for the state to develop its ecotourism sector.

\section{Oil Industry's Impact On Biodiversity}

The Nigerian Oil Industry is located mostly in the mangrove forests. The activities of the numerous oil exploration companies has led to fragmentation, deforestation and degradation of the mangrove forest ecosystem. Mangroverelated biological resources at risk in a spill situation can be affected in at least two principal ways: firstly, from physical effects; secondly, from the true toxicological effects of petroleum (Hoff, 2010). 
Introduction of significant quantities of crude oil into the aquatic ecosystem will cause an increase in biochemical Oxygen demand, reduction in dissolved Oxygen concentration, increased temperature and $\mathrm{pH}$ of the water body.

Oil spills in the Niger Delta have been a regular occurrence, and the resultant degradation of the surrounding environment has caused significant tension amongst the people living in the region. Environmental groups, the Federal Government, and the foreign oil companies operating in the Niger Delta only recently, began to take steps to mitigate these impacts. Large areas of the mangrove ecosystem have also been destroyed. The mangrove forest is in some places no longer in a healthy enough state to sustain wood extraction (Nwilo and Badejo, 2007).

Oil spillages remain the major cause of depletion of vegetative cover and the mangrove ecosystem in the Niger Delta of Nigeria. Crude oil contamination of land affects soil mineral and organic matter content, cation exchange capacity, redox properties and $\mathrm{pH}$ values. It create anaerobic conditions in the soil, which - coupled to waterlogging - may result in accumulation of toxic Aluminium and Manganese ions (Onwurah et al., 2007).

Large areas of the mangrove ecosystem have apparently been destroyed in the Nigerian coastal environment. The mangroves, once a source of both fuel wood for the indigenous people and a habitat for the area's biodiversity, is now unable to survive the oil toxicity of its habitat (Nwilo and Badejo, 2007). The potential impact of this on the carbon cycle is considerable. Mangroves are 'among the most carbon-rich forests in the tropics', and have been reported to store over 1,000 tonnes of carbon per ha. Estimates for Asia vary between 566 and 1,259 tonnes per ha (Kauffmann and Donato, 2012). Data for Africa are lacking. A generic estimate provides an average of 1,031 tonnes of Carbon for the Indo-Pacific region (Donato et al., 2011). Nearly $20 \%$ of this is stored in soils.

Affected mangroves suffer a reduction in levels of stored Carbon. Yeh et al., (2010) assumed a 20-40\% soil Carbon loss from infrastructure activities in conventional oil and gas production as a result of scraping of surface soil for roads, drainage, drill pads, drilling wells, etc. Soil Carbon loss from surface mining would be $70-90 \%$ due to higher disturbance in mining sites and other facilities.

According to Steiner (2008), the Niger Delta can be regarded as a High Consequence Area (HCA) for oil spills. HCAs are defined by a set of criteria under the US regulations on Pipeline Integrity Management in High Consequence Areas, which can be considered a global standard for pipeline safety and integrity. The criteria include it being a populated area, drinking water area or productive ecosystem - all of which apply to the Niger Delta. As an HCA, the Niger Delta should require additional risk reduction measures from oil companies.

\section{Conclusion}

Biodiversity destruction has serious and complex adverse effects on tourist visitation, the health and economies of individual households and Delta State in general. The resultant poverty created from the destruction of the rivers and farmlands which serves as the major sources of income leads to increase in rate of deforestation, through destructions of more oil pipes and operation of illicit refineries for survival, and also resulting to unhealthy feeding habits and sources of earning their income. Petroleum exploitation and production in the Niger Delta over the years have resulted in a number of environmental, socio-economic and political problems in the region. Oil spillage and gas flaring have caused severe environmental damages, loss of plants, animals and human lives, and loss of revenue to both the oil producing companies and the government.

Ecotourism is one the fastest growing segment of tourism and it depends fully on biodiversity as the major attractive resources to thrive. There is need therefore, to protect the biodiversity of Delta state if ecotourism development is to be achieved.

Environmentalists and human right activists should continue in their quest to end this act.

\section{Recommendations}

- Concerted efforts should be made by the ministry of tourism and culture and also ministry of environment towards enforcement of existing policies on a safer, healthier and a cleaner environment in Delta State.

- Immediate cleaning of the environment should be done whenever there is an oil spill to reduce the damage done to the biodiversity.

- Government should as a matter of urgency, make stringent laws and take drastic action against defaulting companies, and not just by payment of fines. Fines for defaulting companies should be so exorbitant so as to deter them.

- Entrepreneurs should take up the task of processing the gas and producing them into cooking/domestic gas. 


\section{References}

Ajugwo, A. O. (2013). Negative Effects of Gas Flaring: TheNigerian Experience. Journal of Environment Pollution andHuman Health, 1 (1): 6-8.

Atubi, A.O. 2015. Effect of Oil Spillage on Human Health in Producing Communities of Delta State, Nigeria. European Journal of Business and Social Sciences, Vol. 4, No. 08

Arowolo, A. A. and Adaja, I. J. 2011. "Trends of natural gas exploitation in Nigeria and the implications on the socioeconomic stability and governance" in the $35^{\text {th }}$ Nigerian Statistical Association annual conference. 2011.

Baird J. 2010. "Oil Shame In Africa" Newsweek July 26th

Brownwen 1999. "The Price of Oil" Human Rights Watch. Retrieved Nov. 9, 2007

Briggs, K.T., Yoshida, S.H. and Gershwin, M.E.1996. The Influence of Petrochemicals and Stresson the Immune System of Seabirds. Regulatory Toxicology and Pharmacology, 23:145-155.

Buchsbaum, D.B. 2004.Ecotourism and Sustainable Development in Costa Rica. Major Paper Submitted to Virginia Polytechnic Institute and State University Master of Public and International Affairs.

CBD (2012): report of the eleventh meeting of the conference of the parties to the convention on biological diversity.convention on biological diversity hydreabed

Christ C., Hillel O., Matus S., Sweeting J. (2003): Tourism and Biodiversity. Mapping Tourism's global footprint. Conservation international pp 66

Donato, D.C., J. B. Kauffman, D. Murdiyarso, S. Kurnianto, M. Stidham, and M.

Drumm, A. \& Moore, A. 2002. An Introduction to Ecotourism Planning (Volume 1), Ecotourism Development, A Manual for Conservation Planners and Managers, USA.

Easy pictures, 2017. Source of river Ethiope Wallpaper for download www.hqpictura.co.uk/source-of-river-ethiope/

Egbe R. E and Thompson D. 2010. Environmental Challenges of Oil Spillage for Families in Oil Producing Communities of the Niger Delta Reg ion, JHER vol. 13, December, 2010, pp 24-34

Emuajaye K. 2012. investigation of the effect of using gas flare to dry tapioca (kpokpogarri) atgana flow station in agbarho, delta state. IOSR journal of applied physics ISSN 2278- 4861, vol. 2 issues pp06-10

Effiong, S. A and. Etowa, U. E. 2012 "Oil spillage cost, gas flaring cost and the life expectancy rate of the Niger Delta people of Nigeria,"Advances in management \& Applied Economics. 2 (2). 211-228.

Egwurugwu, J. N., Nwafor, A., Oluronfemi, O. J., Iwuji, S. C. and Alagwu, E. A. 2013.Impact of Prolonged Exposure toOil and Gas Flares on Human Renal Functions. InternationalResearch Journal of Medical Sciences, 1 (11): 9-16.

Gaston, K. J. and Spicer, J. I. 2004. Biodiversity: an introduction. 2nd edn. Blackwell Publishing, Oxford, UK.

George Oshodi 2009. The Real People of Delta. Black Looks FOE (Friends of the earth). 2004.Gas flaring in Nigeria. http://www.foe.co.uk.

Hoff, R. (2010). Oil spills in mangroves. Planning and response considerations. US Department of Commerce. National Oceanic and Atmospheric Administration NOAA

Hassan, A. and Konhy, R. 2013. "gas flaring in Nigeria; Analysis of changes in it's consequent carbon emission and reporting,"Accounting forum, 37(2). 124-134, 2013

Imevbore A.A. AND Adeyemi, S.A. 1981. Environmental Monitoring in Relations to Pollution and Control of oil pollution. Seminar on the Petroleum Industry and the Nigeria Environment 6.135-142.

Kadafa, A. A. 2012 Environmental Impact of Oil Exploration and Exploitation in Niger Delta of Nigeria. Global journal of science frontier research environmental and earth sciences.

Kauffman, J.B., and Donato, D.C. 2012. Protocols for the measurement, monitoring and reporting of structure, biomass and carbon stocks in mangrove forests.

Working paper 86.Bogor (Indonesia), Center for International Forestry Research

Kindzierski, W.D. 2000. Importance of human environmental exposure to hazardous air pollutants from gas flares. Environmental review, 8, 41-62.

Kiper T. 2013. Role of Ecotourism in Sustainable Development. Advances in Landscape Architecture, chapter 31 pg 773-774

Langeveld JWA, Delany S. 2014. The impact of oil exploration, extraction and transport on mangrove vegetation and carbon stocks in Nigeria. Biomass Research Report Publications available from www.biomassresearch.eu

Manahan, S.E. 1994. Environmental chemistry, 6th edition. Lewis publishing, London, 1994 ISBN.1 56670- 088-4.

Matthew O. 2016. Oil Spillage: Tension as Ukpiovwin, Oghior Communities Lay Claim to Oml 65 in Delta State. Daily Post Nigeria

Medilinkz, 2010. Focus on the environmental impact of gas flaring in Nigeria, 2010. Retrieved from: http://medilinkz.org/news2.asp?News=294 (Accessed on June 5, 2010) 
Maduna A. J., Ogunjimi J.I., Onadeko S. A. 2009. Biodiversity conservation problems and their implications on Ecotourism in Kainji Lake National Park,Nigeria. Journalof sustainable development Africa 10: 59-73

Nemibarini, Z. 2004. Impact Of Extractive Industries on The Biodiversity of The Niger Delta. National Workshop on Coastal and Marine Biodiversity ManagementNigerian Conservation Foundation. 2006. WWF UK and International Union for Conservation of Nature (IUCN), Commission on Environmental, Economic and Social Policy, with Federal Ministry of Environment (Abuja)"Niger Delta Natural Resources Damage Assessment Nigeria Galleria, 2017. Nigeria Galleria .Itsekiri boat regatta festival www.nigeriagalleria.com/Nigeria/States_Nigeria/Delta/Itsekiri-Bofat-Regatta-

Festival-Delta.html and Restoration Project Scoping Report", May 2006.

Nwilo, P.C. and Badejo, O.T. 2007. Impacts and management of oil spill pollution along the Nigerian coast. International Federation of Surveyors. Retrieved 30

September, 2013 from http://www.fig.net/pub/figpub/pub36/chapters/chapter_8.pdf Obioh I.B. 1999. Environmental Impact Assess of Major facilities at QIT,

Atmospheric Emissions and Dispersion Modeling. Faithlink consults Nigeria LTD. Port Harcourt.

Ogbija, T.E Atubi, A.O Ojeh, V.N. 2015.Effects of Environmental Degradation on Human Health in Selected Oil Communities in Delta State. Journal of Environment and Earth Sciencewww.iiste.orgISSN 2224-3216 (Paper) ISSN 2225-0948 (Online)Vol.5, No.9, 2015

Onwurah, I.N.E., Ogugua, V.N., Onyike, N.B., Ochonogor, A.E. and Otitoju, O.F. 2007. Crude oil spills in the environment, effects and some innovative clean-up biotechnologies. InternationalJournal of Environmental Research, Vol. 1, pp.307 320

Onuoha, 2008. Oil Pipeline Sabotage In Nigeria: Dimensions, Actions and Implications For National Security L/C. African Security Review, 17 (3)

Orimoogunje, O. I., Ayaniade, A., Akinkuolie, T. A. and Odiong, A. U. 2013.Perception on the effect of gas flaring on the environment. Research journal of Environmental and Earth Sciences. 2 (4). 188-193

Ovuakporaye, S.I., Aloamaka, C.P., Ojieli A.E., Ejebe, D.E. and Mordi, J.C. 2012.Effect of Gas Flaring On Lung Function among Residents of Ib Gas Flaring Community in Delta State, Nigeria. Research Journal on Earth Science 4(5) 525-528

Powell, C.B., White, S.A., Ibiebele, D..O., B, M., DutKwicz, B., Isoun, M. and Oteogbu, F.U. 1985.Oshika Oil Spill Environmental Impact; Effect on Aquatic Biology.Paper presented at NNPC/FMHE International Seminar on Petroleum Industry and the Nigerian Environment 11-13 Nov. 1985, Kaduna Nigeria 168-178

Steiner R. 2008. Double standards? International Best Practice Standards to Prevent and Control Pipeline Oil Spills, Comparedwith Shell Practices inNigeria, University of Alaska, USA, November 2008.

Travel hub, 2017. Travel hub Nigeria top resorts in Nigeria www.travelhubnigeria.com/top\%20resort.html

Ubani E.C and Onyejekwe, I.M. 2012. Environmental Impact Assessment of Gas Flaring In the Niger Delta Region of Nigeria. American Journal Of Scientific And Industrial Research 4(2). 242-252

Ukoli, M.K. 2005. Environmental factors in the management of the oil and gas industry in a Nigeria. www.cenbank.org

United Nations Development Programme (UNDP).2006. Niger Delta Human Development Report, 2006, p74.UNDP, Niger Delta Human Development Report.

United Nations World Tourism Organization(UNWTO). 2010. Tourism and Biodiversity: Achieving common goals towards sustainability. World Tourism Organization, Madrid

Uyigue, E. and Agho, M. 2007. Coping with Climate Change and Environmental Degradation in the Niger Delta of Southern Nigeria. Community Research and Development Centre Nigeria (CREDC).

World Bank, (1995). Defining and EnvironmentalDevelopment Strategy for the Niger Delta. 1:59

World Health Organization 1994. WHO Guidelines for Drinking water Quality Vol. 1,

1994 World Health Organization, Switzerland, Geneva

Yeh, S., Jordaan, S.M., Brandt, A.R., Turetsky, M.R., Spatari, S. and Keith, D.W. 2010. Land Use Greenhouse Gas Emissions from Conventional Oil Productionand Oil Sands. EnvironSci Technol., Vol. 44, pp.8766-72. DOI: $10.1021 /$ es 1013278

Zabbey N. 2009. Impacts of oil pollution on livelihoods in Nigeria. Paper presented at the conference on "Petroleum and Pollution - How does that impact human rights?

Co- organized by Amnesty International, Forum Syd and Friends of the Earth, Sweden. At Kulturhuset, Stockholm, Sweden; 2009. 